\title{
PENINGKATAN PRODUKSI PETANI BUDIDAYA LELE DI KELURAHAN MAMBURUNGAN TIMUR MELALUI PELATIHAN TEKNOLOGI BIOFLOK
}

\author{
Increased Production Of Farmers Cultivating Catfish In Village Mamburungan East Through \\ Bioflok Technology Training
}

\author{
Awaludin ${ }^{1}$, Diana Maulianawati ${ }^{2}$, Rukisah $^{3}$, Nursia $^{4}$ \\ ${ }^{1.2 .3}$ Budidaya Perairan, Fakultas Perikanan dan Ilmu Kelautan, Universitas Borneo Tarakan, \\ Jl. Amal lama No. 1 Tarakan, Indonesia. \\ ${ }^{4}$ Pendidikan Biologi, Fakultas Keguruan dan Ilmu Pendidikan, Universitas Borneo Takan, \\ Jl. Amal lama No.1 Tarakan, Indonesia
}

\begin{abstract}
ABSTRAK
Peran produksi ikan sebagai benteng ketahanan pangan nasional, hingga kini dinilai masih belum maksimal. Potensi perikanan air tawar di Kota Tarakan sangat menjanjikan hal ini disebabkan tingginya permintaan ikan air tawar. Salah satu komoditi perikanan yang di budidaya di Kota Tarakan yaitu ikan lele. Permintaan ikan lele sangat tinggi menuntut adanya peningkatan produktifitas. Banyak metode yang telah dilakukan dalam meningkatkan produksi, salah satunya adalah teknologi bioflok. Teknologi bioflok adalah teknik manajemen kualitas air yang didasarkan pada pertumbuhan dan pengendalian bakteri. Teknologi bioflok mampu memperbaiki kualitas air dan dapat dijadikan pakan langsung oleh organisme budidaya, sehingga mampu mengurangi biaya produksi. Teknologi ini telah banyak diaplikasikan pada organisme budidaya salah satunya adalah ikan lele. Teknik budidaya ikan lele yang dilakukan di Tarakan dengan menggunakan metode konvensional sehingga biaya produksi tinggi, penggunaan pakan yang tinggi serta tingkat kelulusanhidupan ikan lele rendah. Sehingga pelatihan yang dilakukan di Kelurahan Mamburungan Timur Kota Tarakan bertujuan untuk meningkatkan produksi petani budidaya ikan lele dengan menggunakan teknologi bioflok.
\end{abstract}

Kata kunci : Budidaya, Ikan Lele, Kota Tarakan, Teknologi Bioflok, Perikanan Air Tawar

\begin{abstract}
The role of fish production as a bulwark of national food security, up to now the votes are still not optimally. The potential of fresh water fishing in the town of Tarakan very promising this is due to the high demand for freshwater fish. One of the fishery commodities in cultivation in the town of Tarakan i.e. catfish. Demand for catfish very high sue an increase in productivity. Many methods have been done in improving production, one of which is bioflok technology. Bioflok technology is a management technique of water quality based on the growth and control of bacteria. Bioflok technology is able to improve water quality and can be used directly by organisms feed cultivation, thereby being able to reduce production costs. This technology has been extensively applied to the aquaculture organisms one is catfish. The technique of cultivating catfish done at Tarakan by using conventional methods so that the production cost is high, the use of feed that is high as well as low level of catfish kelulusanhidupan. So the training conducted in a neighborhood east of the town of Tarakan Mamburungan aims to increase the production of farmers cultivating catfish using bioflok technology.
\end{abstract}

Keywords: Cultivation, Catfish, Tarakan City, Bioflok Technologies, Freshwater Fishing

\section{PENDAhuluan}

Peran produksi ikan sebagai benteng ketahanan pangan nasional, hingga kini dinilai masih belum maksimal. Padahal, dengan potensi yang dimiliki Indonesia, ikan berpeluang menggantikan lauk pauk berbahan nabati sebagai pendukung utama ketahanan pangan. Oleh karena itu, 
Pemerintah Indonesia ditantang untuk terus melakukan inovasi untuk memanfaatkan ikan sebagai penopang ketahanan pangan utama.Kalimantan Utara (Kaltara) adalah provinsi baru di Indonesia yang terletak di bagian utara Pulau Kalimantan. Provinsi ini berbatasan langsung dengan negara tetangga, yaitu Negara Bagian Sabah dan Serawak, Malaysia Timur (Anonim, 2017). Provinsi Kaltara terdiri dari 5 kabupaten/kota antara lain kabupaten Bulungan, Kabupaten Malinau, Kabupaten Nunukan, Kabupaten Tana Tidung dan Kota Tarakan. Komoditi ikan air tawar yang banyak dibudidayakan serta memiliki nilai ekonomi yang relative tinggi dan mudah dibudidayakan yaitu ikan lele. Produksi ikan lele harus dapat ditingkatkan, hal ini karena permintaan pasar yang cukup tinggi, tetapi yang menjadi kendala dalam budidaya ikan lele yaitu penggunaan teknologi budidaya yang masih sederhana serta manajemen pemberian pakan yang tidak benar menyebakan rendahnya produktifitas serta meningkatkan biaya produksi terutama untuk pakan dan faktor kualitas air juga menjadi kendala utama di dalam budidaya lele. Salah satu teknik yang dapat digunakan dalam memperbaiki kualitas ikan, penggurangan penggunaan pakan serta meningkatkan produktifitas adalah dengan menggunakan metode budidaya bioflok.

Di beberapa negara seperti Israel, Amerika Tengah, dan beberapa negara lainnya telah membuktikan keberhasilan teknologi bioflok baik untuk nila merah, udang vaname, dan udang windu (Avnimelech dan Ritvo, 2003). Budidaya udang vanamae sistem bioflok di Indonesia telah dikembangkan di beberapa
VOLUME 2 NOMOR 2 DESEMBER 2018

(Halaman 52-57)

daerah di Indonesia beberapa tahun terakhir ini tetapi untuk budidaya ikan air tawar baru dikembangkan di Indonesia. Teknik bioflok dapat memberikan keuntungan terutama dalam mempertahankan kualitas air dan efisiensi pakan 10\%-20\% (Pantjara dkk., 2010).

Teknologi bioflok adalah teknik manajemen kualitas air yang didasarkan pada pertumbuhan dan pengendalian bakteri heterotrof di dalam system budidaya dengan zero water exchange (Ekasari, 2008). Bakteri heterotrof memerlukan sumber karbon sebagai sumber energi untuk tumbuh (Avnimelech, 2012). Bakteri heterotrof mampu menurunkan total ammonia nitrogen, nitrit dan nitrat dalam media budidaya (baik skala laboratorium maupun skala massal) (Ekasari, 2008). Flok yang terbentuk dari bioflok dapat dijadikan sebagai pakan alami bagi organisme budidaya sehingga mampu mengurangi biaya pakan dan meningkatkan produktivitas. Azhar (2013) melaporkan bahwa udang vanamei yang dibudidaya dengan menggunakan teknologi bioflok memiliki nilai konversi kapan yang lebih rendah dibandingkan dengan tanpa penggunakan bioflok.

Pemeliharaan ikan lele dalam budidaya dengan menggunakan teknologi bioflok karena ikan lele dapat dipelihara dengan padat penebaran tinggi, sehingga dengan penggunaan teknologi bioflok mampu mengurangi biaya produksi dan menghasilkan produksi yang tinggi. Diharapkan dengan dilaksanakan kegiatan ini mampu meningkatkan produksi ikan lele bagi petani lele di kelurahan Mamburungan Timur. 


\section{METODE}

Ada beberapa pendekatan yang dilaksanakan yaitu, tinjauan lokasi pelaksanaan, sosialisasi (pembekalan), dan pelatihan. Lokasi kegiatan dilaksanakan di Mamburungan Timur Kota Tarakan. Sebelum dilaksanakan kegiatan terlebih dahulu dilakukan survei lokasi. Hal ini bertujuan agar kegiatan dapat berjalan dengan baik. Sosisalisasi bertujuan untuk menyampaikan materi keilmuan yang berkaitan dengan teknologi bioflok, seperti metode bioflok, manfaat bioflok dalam budidaya ikan. Sebelum pelatihan dilakukan alat dan bahan yang digunakan disiapkan terlebih dahulu. Langkahlangkah dalam budidaya ikan lele dengan menggunakan metode bioflok, meliputi:

\section{a. Persiapan kolam budidaya}

Kolam yang digunakan pada kegiatan pelatihan ini adalah bak terpal berbentuk bundar dengan volume $8 \mathrm{~m}^{3}$. Bak dilakukan pengisian air dan diberi aerasi selama 2 hari, kemudian air pada media pemeliharaan sebelum digunakan terlebih dahulu dilakukan sterilisasi dengan menggunkan kaporite 15-30 $\mathrm{g} / \mathrm{m}^{3}$ selama 1-2 hari, kemudian dilakukan penambahan Natrium Thiosulfat sebanyak 15-30 $\mathrm{g} / \mathrm{m}^{3}$ selama 6 jam. .

b. Penumbuhan bakteri bioflok

Tahap awal sebelum dilakukan penebaran benih lele, dilakukan penumbuhan bakteri bioflok pada media pemeliharaan dengan melakukan penambahan probiotik 100 $\mathrm{ml} / \mathrm{m}^{3}$, kemudian dilakukan penambahan molase $0,02 \mathrm{~g} / \mathrm{m}^{3}$, dan kapur sebanyak $1 \mathrm{~g} / \mathrm{m}^{3}$ selama proses fermentasi dibiarkan selama 2-3 hari.

\section{c. Penebaran benih ikan lele}

Padat penebaran ikan lele dengan menggunakan teknologi bioflok dalam pemanfaatkan bakteri dapat dilakukan padat tebar yang sangat tinggi. Padat penebaran ikan lele 800 ekor $/ \mathrm{m}^{3}$ dengan ukuran $(7-10 \mathrm{~cm})$.

d. Pakan

Pakan yang akan digunakan terlebih dahulu dilakukan fermentasi dengan menambahkan 1-2 $\mathrm{mg} / \mathrm{l}$ molase, bakteri probiotik $2 \mathrm{ppm}$. Pakan yang digunakan 3-5\% perhari/berat badan.

e. Kualitas air

Air media pemeliharaan setiap hari harus selalu dicek (suhu, $\mathrm{pH}$, dan volume floc). Buangan endapan dilakukan secara bertahap, 1 bulan pertama dilakukan seminggu sekali, bulan kedua dilakukan seminggu 2 kali dan bulan ketiga setiap 2 hari sekali.

\section{SOPBIOFLOK}

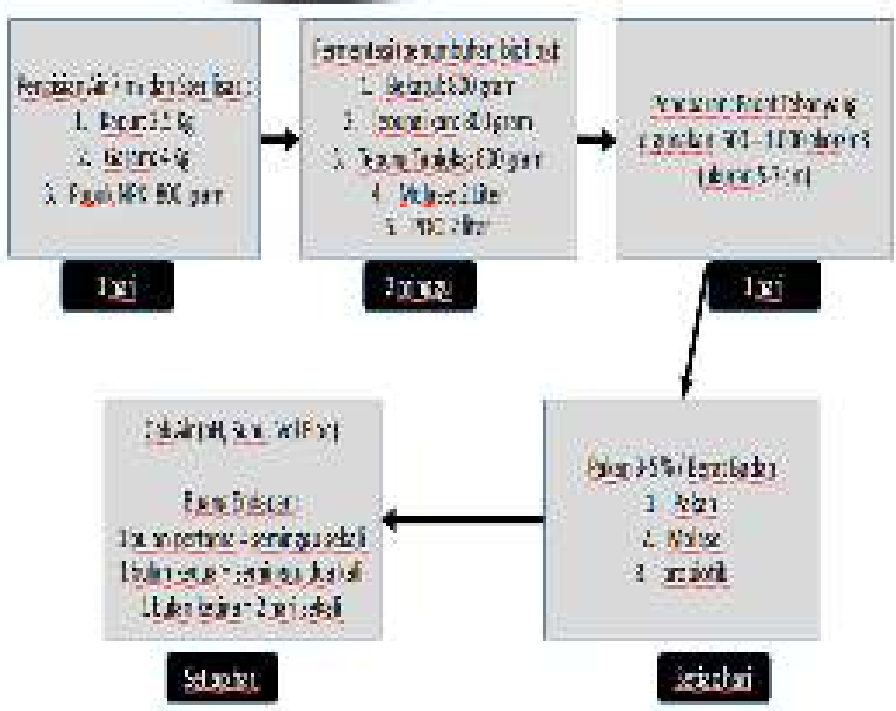

Gambar 1. Standar Operasional Prosedur Sistem Bioflok 


\section{HASIL DAN PEMBAHASAN}

Kegiatan pelatihan budidaya dengan siste, bioflok dilakukan melalui beberapa tahapan. Capaian setiap tahapan kegiatan adalah sebagai berikut:

\section{Tahapan Sosialisasi}

Tahapan sosialisasi meliputi persiapan, koordinasi dengan peserta dan kegiatan sosialisasi. Sosialisasi (pembekalan) materi tentang budidaya bioflok dilakukan di Fakultas Perikanan dan Ilmu Kelautan Universitas Borneo Tarakan dengan Mitra yaitu Kelompok Tani Karungan Maju Bersama. Sosialisasi dilakukan dengan tujuan untuk memberikan informasi tentang budidaya ikan lele dengan menggunakan sistem bioflok dan permasalahan yang dialami oleh kelompok mitra. Capaian kegiatan ini adalah 100\%, dimana para anggota Kelompok Tani Karugan Maju Bersama, dapat mengikuti kegiatan sosialisasi serta terjadi diskusi yang aktif antara peserta dan pemateri (Gambar 2).

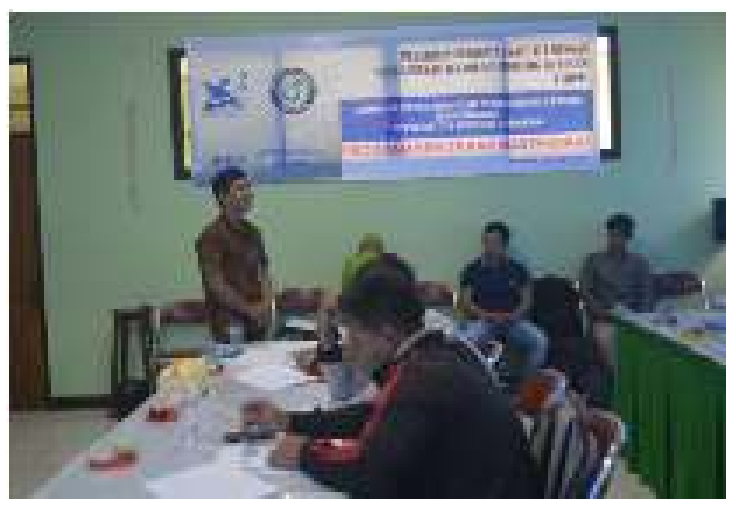

Gambar 2. Sosisalisasi Teknik Bioflok

\section{Tahapan Persiapan Wadah Bioflok}

Pemiliharan ikan lele dengan sisten bioflok dilakukan di laboratorium mini Hatchery FPIK UBT sebagai kolam percontohan. Mitra diikut sertakan dalam persiapan hingga pemanenan ikan lele Awaludin, Diana M, Rukisah, Nursia., PENINGKATAN PRODUKSI PETANI...
VOLUME 2 NOMOR 2 DESEMBER 2018

(Halaman 52-57)

dengan sistem bioflok. Langkah awal yaitu persiapan bak budidaya ikan lele yang akan digunakan. Kolam yang digunakan merupakan bak terpal dengan volume $8 \mathrm{~m}^{3}$ berbentuk bulat (Gambar 3). Sebelum digunakan terlebih dahulu bak terpal didesinfektan dengan menggunakan kaporit kemudian dinetralkan dengan menggunakan natrium thiosulfate.

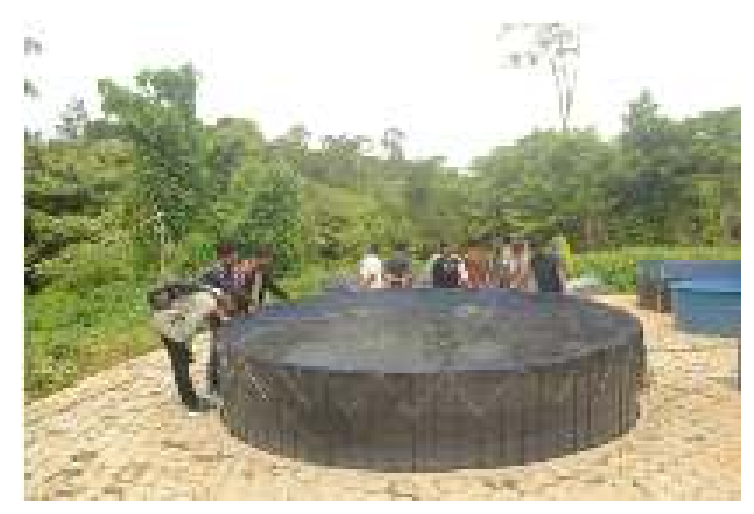

Gambar 3. Bak Terpal

Kolam yang telah bersih kemudian dilakukan pengisian air sebanyak $7 \mathrm{~m}^{3}$. Capaian tahapan ini adalah $100 \%$, di mana peserta dapat memahami proses awal persiapan kolam bioflok.

\section{Tahapan Penumbuhan Flok}

Tahapan selanjutnya adalah menumbuhakan bakteri bioflok. Pada hari pertama dilakukan penambahan kapur, pupuk NPK dan garam diberi aerasi selama 1 hari. Pada hari kedua kemudian ditambahkan molase, tepung ikan, tepung tapioca dan probiotik diberi aerasi dan dibiarkan selama 2 minggu dalam proses fermentasi, dengan tujuan untuk menumbuhkan bioflok. Setiawan et al (2016) menyebutkan bahwa dengan metode bioflok bertujuan untuk meningkatkan efesiensi pemanfaatan pakan dengan pembentukan biomassa mikrobadari bahan organik dan senyawa 
terlarut. Capaian tahapan ini adalah 100\% dimana semua anggota kelompok tani, ikut berpartisipasi dan melaksanan proses penumbuhan bakteri bioflok.

\section{Tahapan Penebaran Benih dan Pemeliharaan}

Mitra juga mengikuti kegiatan penebaran benih. Penebaran ikan lele dilakukan setelah tahapan fermentasi. Ikan lele yang ditebar dengan padat penebaran 800 individu $/ \mathrm{m}^{3}$. Dengan menggunakan bak terpal dengan volume $7 \mathrm{~m} 3$ padat tebar 5.600 individu dengan ukuran $3-5 \mathrm{~cm}$. Selama pemeliharaan ikan lele hal yang penting diperhatikan yaitu pakan, baik jenis pakan, cara pemberian, waktu pemberian dan nutrisi pakan, karena pakan merupakan faktor penentu keberhasilan dalam budidaya ikan lele.

Menurut Craigh dan Helfrich (2002), meskipun melalui menajemen yang baik, pakan yang diberikan pada ikan pasti akan menghasilkan limbah. Pakan yang akan digunakan dalam terlebih dahulu difermentasi selama 2 hari dengan menambahkan molase dan probiotik dengan tujuan meningkatkan nutrisi pada pakan tersebut. Pemberian pakan dengan dosis 2-3 \% perBB dengan frekuensi pemberian 2 kali yaitu pagi dan sore hari.

Pengontrolan $\mathrm{pH}$ setiap tiga hari sekali dilakukan dengan tujuan untuk mengetahui kerja bakteri. Jumlah flok dalam media pemeliharaan juga harus selalu dikontrol agar tidak terjadi blomming alga. Warna air pemeliharaan harus selalu dikontrol, dengan warna air berwarna coklat (Gambar 4.). Capaian tahapan ini adalah $100 \%$, dimana flok dapat tumbuh dengan baik pada media pemeliharaan. 


\section{DAFTAR RUJUKAN}

Avnimelech Y. 2012. Biofloc technologya practical guide book, $2 \mathrm{~d}$ edition. World Aquaculture Society, Baton Rouge, Louisiana, United State.

Avnimelech, Y. dan G. Ritvo. 2003. Shrimp and fish pond soils: processes and management. Aquaculture, $220: 549-567$

Azhar MH. 2013. Peranan sumber karbon eksternal yang berbeda dalam pembentukan bioflok pada budidaya budidaya udang vanamei (Litopenaeus vannamei). (Tesis). Bogor (ID): Institut Pertanian Bogor

Craigh S. \& Helfrich LA., 2002, Understanding Fish Nutrition, Feeds, and Feeding, Viginia Coperative Extension Service. Publication

Ekasari J. 2008..bio-flocs technology: the effect of different carbon source, salinity and the addition of probiotics on the primary nutritional value of the bio-flocs (tesis). Gent : Faculty of Bioscience Engineering, Ghent University.

Pantjara, B., Utojo dan M. Mangampa. (2008). Kesesuaian Lahan Budidaya Tambak di Kecamatan Watubangga Kabupaten Kolaka, Sulawesi Tenggara. Jurnal Riset Akuakultur. 3(1)

Setiawan, Rizky Ariqoh, Pratiwi Tivani, Laras Pipih dan Isti Pudjiastuti. Bioflokulasi Sistem Teknologi Budidaya Lele Tebar Padat Tinggi Dengan Kapasitas 1M3/750 Ekor Dengan Flock Forming Bacteria. Inovasi Teknik Kimia, Vol. 1, No. 1, April 2 